\title{
Influence of fish oil in the concentration of conjugated linoleic acid and omega 6 and 3 in buffalo milk
}

\author{
[Influência do óleo de peixe na concentração de ácido linoléico conjugado e \\ Omega 6 e 3 no leite de búfalas]
}

\author{
E.M. Patiño ${ }^{1}$, M.A. Judis ${ }^{2}$, M. Sanchez Negrette ${ }^{1}$, D.O. Pochon ${ }^{1}$, J.F. Cedres ${ }^{1}$, \\ G. Rebak $^{1}$, A.M. Romero ${ }^{2}$, M.M. Doval ${ }^{2}$, G.A. Crudeli ${ }^{1}$ \\ ${ }^{1}$ School of Veterinary Science - Universidad Nacional del Nordeste \\ Sargento Cabral 2139 - Corrientes (3400), Argentina \\ ${ }^{2}$ School of Agribusiness - Universidad Nacional del Chaco Austral \\ Presidencia Roque Sáenz Peña - Chaco, Argentina
}

\begin{abstract}
The aim of this research work was to investigate the influence of fish oil supplementation on the concentration of conjugated linoleic acid (CLA) and omega 6 and 3 in samples of buffalo milk. A total of 24 female buffaloes separated at random into three groups were fed for 49 days with: natural pasture (group I), supplemented with $70 \mathrm{~mL}$ of fish oil (group II) and $140 \mathrm{~mL}$ of fish oil (group III). In the experiment the concentration of CLA showed differences $(\mathrm{P}<0.05)$ among the three groups, with a maximum of $7.14 \mathrm{mg} / \mathrm{g}$ fat in group II. No significant differences were found in omega- 6 among the three groups. The highest value of $3.82 \mathrm{mg} / \mathrm{g}$ fat corresponded to group I, whicht had not been supplemented with fish oil. Significant differences were observed in omega $3(\mathrm{P}<0.05)$ in groups II and III with respect to group I. The highest average value of $2.42 \mathrm{mg} / \mathrm{g}$ fat was obtained in group III. The closest relationship omega 6/3 (1.37:1) was observed in group III. As a result, the diets of groups II and III, which included fish oil, increased significantly the content of CLA and omega 3 with reductions in levels of omega 6.
\end{abstract}

Keywords: Bubalus bubalis, milk, CLA, Omega 6 and 3, fish oil

\section{RESUMO}

Estudou-se a influência da suplementação com óleo de peixe sobre a concentração dos ácidos graxos ômega 6 e 3, mostrado no leite de búfala. Foram utilizadas 24 búfalas aleatoriamente selecionadas e distribuídas em três grupos e alimentados com pastagem natural por 49 dias com: nenhum suplemento (grupo I), suplementado com $70 \mathrm{~mL}$ de óleo de peixe (grupo II) e com 140mL de óleo de peixe (grupo III). A concentração de CLA diferiu $(P<0,05)$ entre os três grupos, com valores máxima de até $7,14 \mathrm{mg} / \mathrm{g}$ de gordura no grupo II. Não foram observadas diferenças significativas para os ácidos graxos omega 6, sendo o maior valor de 3,82 $\mathrm{mg} / \mathrm{g}$ de gordura no grupo I. Foi observada diferença significativa quanto aos ácidos graxos ômega $3(P<0,05)$ nos grupos II e III em relação ao grupo I. O mais elevado valor, $2,42 \mathrm{mg} / \mathrm{g}$ de gordura foi observado no grupo III. A relação ômega 6/3 mais estreita, 1,37:1, foi observada no grupo III. Os resultados mostram que os animais dos grupos II e III que receberam suplementação de óleo de peixe aumentou significativamente o teor de CLA e de omega 3, com diminuição de omega 6.

Palavras-chave: Bubalus bubalis, leite, CLA, ômega 6 e 3, óleo de peixe

Recebido em 1 de novembro de 2011

Aceito em 12 de janeiro de 2012

E-mail: exepa@vet.unne.edu.ar 


\section{INTRODUCTION}

Consumption of saturated fatty acids in milk and meat from ruminants is associated with an increased incidence of coronary heart disease in human beings (Menotti et al.,1999). The fat from ruminant products is frequently considered harmful to human health due to the high saturated fatty acid content. However, a fat component, the conjugated linoleic acid (CLA) contains anticancer and hypocholesterolemic properties and prevents arteriosclerosis and diabetes (National..., 1996). CLA is the term used to describe one or more positional and geometric isomers of linoleic acid (cis-9, cis-12, octadecadienoic acid), which contains double conjugated bonds. Such bonds are usually found in positions 9 and 11 , or 10 and 12 . They can be cis or trans configuration. The CLA biologically active form would be represented by the isomer cis-9, trans-11 CLA (also called rumenic acid), representing 80 to $90 \%$ of total CLA in milk fat (Belury, 2002).

It has been shown that CLA inhibits the carcinogenesis onset in skin tumors, in tumors of the stomach and in mammary gland tumors, all of them induced experimentally with different carcinogens in mice (Ha et al., 1990; Ip et al., 1994). Hypocholesterolemic properties have been demonstrated in pilot studies with hamsters fed with a hypercholesterolemic diet and supplemented with CLA. This experiment showed a significant reduction in total cholesterol, LDL-cholesterol and triglycerides (Nicolosi et al., 1993). Hypocholesterolemic properties were also demonstrated in rabbits supplemented with CLA (Lee et al., 1994).

Linoleic and linolenic acids are essential fatty acids, synthesized by plants but not by mammals. These acids, therefore, must be supplied by food. They are the precursors for the synthesis of polyunsaturated fatty acids (PUFA) in the series omega 3 and omega 6, respectively (Gagliostro, 2004).

CLA precursors are the PUFAs present in the forage feed for ruminant as linoleic acid (cis9,trans-12 C18: 2) and $\alpha$-linolenic acid. The former abounds in corn silage, cereals and various oilseeds such as sunflower and soybean. $\alpha$-linolenic acid is present in greater percentage in green pasture and flax. (Gagliostro, 2004). The transformation of unsaturated fatty acids occurs in the rumen by bacteria of the genus Butyrivibrio through ruminal biohydrogenation, which can be improved by a strategic diet rich in unsaturated fatty acids. This improves the salubrity of milk and meat from ruminants due to higher CLA and omega 3 concentrations (Menotti et al., 1999; Chilliard et al., 2000).

Studies have shown that omega 3 fatty acids, eicosapentaenoic acid (EPA) and docosahexaenoic (DHA) have hypocholesterolemic, antitrombic and antiinflammatory properties in human beings (Williams, 2000). Moreover, experimental studies with laboratory animals indicate that the incidence of colon tumors is lower in animals fed with diets enriched with fish oil than in animals fed with a diet rich in saturated fat or vegetable oil (Reddy and Sugie, 1988; Rao et al., 2001).

Other research works have shown that diets enriched with fish oil decreased the development of colon tumors implanted in mice (Cannizzo and Broitman, 1989; Tisdale and Dhesi, 1990) and colon tumors in nude mice (Calder et al., 1998).

In human health the concept of the relationship omega 6/omega 3 is convenient to be used (Gagliostro, 2004). A lower ratio of omega6/omega-3 fatty acids is more desirable in reducing the risk of many of chronic diseases of high prevalence in Western societies, as well as in developing countries (Simopoulos, 2002).

The main sources of CLA in human diets are milk and dairy products, which contain mainly cis-9, trans-11 C18:2 (rumenic acid) and trans-9, cis-11 C18:2. (Gagliostro, 2004).

Many factors can influence the increase of CLA in buffalo milk: seasonal factors (Talpur et al., 2008) and the number of lactations (Van Nieuwenhove et al., 2004) but in reality the animal's diet is what has greatest emphasis in increasing the CLA (Bergamo et al., 2003; Secchiari et al., 2005; Patiño et al., 2010).

The research works carried out in buffaloes that determined CLA in milk in countries such as Italy (Fedele et al., 2001), Pakistan (Sechiari et al., 2005; Talpur et al., 2007; 2008), India (Tyagi et al., 2007), Brazil (Medeiros 2002; Oliveira et al., 2009; Caldeira et al., 2010) and Argentina 
(Van Nieuwenhove et al., 2004; 2007; Patiño et al., 2008; 2010) obtained different values due to the different diets used.

This work aimed at investigate whether fish oil supplementation in the diet of buffaloes bred in the Province of Corrientes and fed on natural pastures modifies the CLA concentrations, the omega-3 and 6 fatty acids and whether that supplementation improves the omega $6 / 3$ relationship in the milk.

\section{MATERIAL AND METHODS}

The animals used belong to a herd from a farm located in the town of San Cosme $35 \mathrm{~km}$ from the city of Corrientes, Province of Corrientes, Argentina. 24 multiparous buffaloes of Murrah breed and Murrah x Mediterranean crossbred were used, identified with alphanumeric caravans, distributed in three groups, consisting of eight animals each. All animals were fed in natural pastures during the 49-day experiment. Control group I was fed only with natural pastures, group II was fed daily with $70 \mathrm{~mL}$ of fish oil and group III with $140 \mathrm{~mL}$ of fish oil. The animals supplemented with fish oil, made of $85 \%$ argentine haddock (Merluccis hubbsi) and 15\% anchovy (Anchoa marinii), (Table 1) received the ration at milking time in an individual feeder to meet the assumption of independence.

Table 1. Fish oil composition

\begin{tabular}{lc}
\hline Fatty acids composition & $(\%)$ \\
\hline Alfa linoleic 18:3 n-3 & 1.10 \\
Estearidonic acid 18:4 n-3 & 2.58 \\
Eicosatrienoic acid 20:3 n-3 y n-6 & 0.16 \\
Arachidonic acid 20:4 n-3 & 0.62 \\
Eicosapentaenoic acid EPA 20:5 n-3 & 7.18 \\
Eneicosapentaenoic acid 21:5 n-3 & 0.23 \\
Docosapentaenoic acid DPA 22:5 n-3 & 0.70 \\
Docosahexaenoic acid DHA 22:6 n-3 & 16.47 \\
Fatty acids n-3 & 29.04 \\
Fatty acids n-6 & 3.52 \\
PUFAs & 32.56 \\
Free fatty acids & 0.43 \\
Other & 5.41 \\
\hline
\end{tabular}

The natural pasture was composed mainly by species such as Andropogon lateralis, A. sellononaus, Cynodon dactylon, Elionorus sp., Paspalum notatum, P. Almuna chase, Sorghastrum agrostoides, Desmodium canum and Shylosanthes macrosonics.
The buffaloes were milked by hand in the morning. The samples $(n=24)$ were obtained in the beginning and in the end of day 49 in the experiment carried out between May and July 2009 during the second stage of lactation of the experimental herd. During the milking routine and after discarding the first streams, samples of $200 \mathrm{~mL}$ of milk were taken from each animal. The samples were packed in disposable containers, frozen at $-20^{\circ} \mathrm{C}$ and kept in polyurethane boxes until they were taken to the laboratory.

Each sample was processed in duplicate to obtain the lipid profile. To obtain the total lipids, a mixture of chloroform and methanol according to the Bligh and Dyer technique (1959) was used. The conversion of fatty acids in methyl esters was carried out with methanol $\mathrm{NaOH}$ and $\mathrm{BF}_{3}$ at $14 \%$ boiling for 8 minutes. The methyl esters were obtained with hexane and analyzed with a gas chromatograph. Standards of methyl esters of 99\% pure fatty acids (Lipid Standard 189-19 Sigma-Aldrich) were used. The fatty acid composition was determined in an Agilent gas chromatograph equipped with a capillary column $60 \mathrm{~mm}$ long and $0.25 \mathrm{~mm}$ of internal diameter (Supelco 2340) and a flame ionization detector. The gas chromatography method used (GC-FID) met the ISO 15304 standard (2010).

The dependent variables studied were: conjugated linoleic acid (CLA) rises from quantifying the conjugated linoleic acid isomers with double bonds: CLA: 18:2, 9c, 11t; CLA: 18:2, 12c, 10t ; CLA: 18:2, 10c, 12c.

Omega 6, composed by the following fatty acids: C 18:2 n-6 t linolelaidic acid; C 18:2 n-6 c; linoleic acid; C 18:3 n-6 gama linolenic acid; C 20:2 n-6 eicosadienoic acid; C 22:2 n-6 docosadienoic acid; C 20:3 n-6 eicosatrienoic acid; C 20:4 n-6 arachidonic acid.

Omega 3 composed by the following fatty acids: C 18:3 n-3 alfa linolenic acid; C 20:3 n-3 eicosatrienoic acid; C 20:5 n-3 eicosapentaenoic acid; C 22:6 n-3 docosahexaenoic acid.

Descriptive statistics was applied to assess the sample estimates for each treatment (mean, standard deviation, coefficient of variation and minimum and maximum ranges). Prior to analysis, the performance description of the 
sample using confidence intervals and box \& whisker charts was used. The basic assumptions of the analysis of variance, consistency and standardization, were also checked. In order to infer the effects of the diet, a randomized design with the linear model was carried out. The calculations were performed with the help of the Infostat software (Infostat..., 2009), owned by the School of Veterinary Sciences of the Universidad Nacional del Nordeste.

\section{RESULTS AND DISCUSSION}

The CLA milk content of buffaloes fed with the three diets is shown in Table 2. On day 49 there were significant differences $(\mathrm{P}<0.05)$ among the three groups (Table 2). The highest average value of CLA $(7.14 \mathrm{mg} / \mathrm{g}$ fat) was obtained from the buffaloes belonging to group II. Group II had an increase of $86.42 \%$ compared to Group I. In contrast group III, which received more oil supplementation, had a significant increase of $59.8 \%$ compared to group I. However, it was not higher than group II fed with less than half of the fish oil.

It has been shown that fish oil in the diet of ruminants is very effective to increase CLA fatty acids and omega 3 in milk fat.

Table 2. CLA content ( $\mathrm{mg} / \mathrm{g}$ fat) in milk of buffaloes of different groups on day 49

\begin{tabular}{llllllll}
\hline \multicolumn{1}{c}{ Groups } & $\mathrm{n}$ & Mean & SD & CV & Min & Max & Dif \\
\hline I & 8 & 3.83 & 1.14 & 29.28 & 2.27 & 5.13 & $\mathrm{a}$ \\
II & 8 & 7.14 & 1.78 & 24.97 & 4.97 & 10.23 & $\mathrm{~b}$ \\
III & 8 & 6.12 & 1.67 & 27.32 & 3.55 & 7.54 & $\mathrm{c}$ \\
\hline
\end{tabular}

SD: standard deviation, CV: coefficient of variation; Min and Max: ranges; Dif: difference (different letters indicate significant differences between mean, $\mathrm{P}<0.05$ ).

In the present experiment it was observed that the increase of the CLA fatty acids and Omega 3 was related to the incorporation of the fish oil in the diet provided. However, a higher increase of these fatty acids was obtained when using low amounts of fish oil in the diet. This is due to the process of biohydrogenation in the rumen, which causes a toxic effect when the amount of fish oil is exceeded. The amount of unsaturated fatty acids provided in the diet has a toxic effect on the microbial metabolic activity (CLA producer), mainly on the Butyrivibrio fibrisolvens microorganism with the consequent decrease in the production of CLA fatty acid (Maia et al., 2010).

The highest average value of CLA obtained in this experiment, was higher than those recorded in Brazil by Oliveira et al. (2009) with diets based on corn and soybean $(5.08$ to $6.91 \mathrm{mg} / \mathrm{g}$ fat). However, this value was lower in diets with soybean oil, (10.80mg/g fat) and in buffaloes fed only with Brachiaria grass (Brachiaria decumbens) the value was $11.0 \mathrm{mg} / \mathrm{g}$ fat (Caldeira et al., 2010). Values were also lower than those obtained in India by Tyagi et al. (2007) in Murrah buffaloes with concentrated diets (7.7mg/g fat), concentrates plus clover (Trifolium alexandrium) (13.4mg/g fat) and entirely clover (17.0mg/g fat).

The omega- 6 fatty acid content in the milk of buffaloes fed with the three diets is shown in Table 3. There were no significant differences among the three groups. The highest value was $3.82 \mathrm{mg} / \mathrm{g}$ fat in group $\mathrm{I}$, a group not supplemented with fish oil. The highest average value of omega- 6 found in this research work $(3.82 \mathrm{mg} / \mathrm{g}$ fat $)$ is lower than the average value quoted in Brazil $(7.2 \mathrm{mg} / \mathrm{g}$ fat) by Caldeira et al. (2010) and below the average value recorded in India (16.4mg/g fat) by Tyagi et al. (2007) with a diet based on clover.

Table 3. Omega 6 (mg/g fat) in milk of buffaloes from different groups on day 49

\begin{tabular}{llllllll}
\multicolumn{1}{c}{ Groups } & N & Mean & SD & CV & Min & Max & Dif \\
\hline I & 8 & 3.82 & 0.80 & 20.21 & 2.34 & 4.45 & $\mathrm{a}$ \\
II & 8 & 3.28 & 1.08 & 32.84 & 1.21 & 4.43 & $\mathrm{~b}$ \\
III & 8 & 3.31 & 0.78 & 23.72 & 1.96 & 4.28 & $\mathrm{c}$ \\
\hline
\end{tabular}

SD: standard deviation, CV: coefficient of variation; Min and Max: ranges, dif: difference (different letters indicate significant differences between mean, $\mathrm{P}<0.05)$. 
The omega-3 fatty acid content of the three diets is shown in Table 4. Significant differences $(\mathrm{P}<0.05)$ between groups II and III when compared to group I were found. The highest average value $(2.42 \mathrm{mg} / \mathrm{g}$ fat) was obtained in Group III with an increase of $56.1 \%$ compared to Group I. Group II $(2.30 \mathrm{mg} / \mathrm{g}$ fat $)$ showed an increase of $48.4 \%$ compared to Group I. The omega-3 highest average value found in our experiment $(2.42 \mathrm{mg} / \mathrm{g}$ fat) was below the average obtained in India $(14.2 \mathrm{mg} / \mathrm{g}$ fat) by Tyagi et al. (2007) with the diet based on clover. This shows the importance of green pasture in the increase of fatty acid concentration. Due to the results obtained in our experiment and when compared with other authors we can infer that the best values are obtained with implanted pastures, but acceptable results are also achieved with green natural pastures.

The omega $-6 /-3$ relationship in buffalo milk is shown in Table 5. Diets supplemented with fish oil improved the omega $-6 /-3$ relationship. The closest relationship was that of group III $(1.37: 1)$ at the end of the experiment. In India, Tyagi et al. (2007) achieved an omega $-6 /-3$ relationship of $1: 1$ with the diet based on clover.

Table 4. Omega 3 (mg/g fat) in milk of buffaloes from different groups on day 49

\begin{tabular}{llllllll}
\hline \multicolumn{1}{c}{ Groups } & N $^{\text {o }}$ & Mean & SD & CV & Min & Max & Dif \\
\hline I & 8 & 1.55 & 0.73 & 20.93 & 0.99 & 1.87 & $\mathrm{a}$ \\
II & 8 & 2.30 & 0.43 & 18.57 & 1.60 & 2.98 & $\mathrm{~b}$ \\
III & 8 & 2.42 & 0.73 & 30.12 & 1.19 & 3.09 & $\mathrm{~b}$ \\
\hline
\end{tabular}

SD: standard deviation, CV: coefficient of variation, Min and Max: ranges, Dif: difference (different letters indicate significant differences between mean, $\mathrm{p}<0.05)$.

Table 5. Ratio of omega 6/3 (mg/g fat) in milk from buffaloes of different groups

\begin{tabular}{lcccccc}
\multirow{2}{*}{ Groups } & \multicolumn{3}{c}{ Day 0} \\
\cline { 2 - 7 } & $6 \Omega$ & $3 \Omega$ & Relation: $\Omega 6 / 3$ & $6 \Omega$ & $3 \Omega$ & Relation: $\Omega 6 / 3$ \\
\hline I & $1.83 \pm 1.01$ & $0.78 \pm 0.32$ & $2.35: 1$ & $3.82 \pm 0.80$ & $1.55 \pm 0.34$ & $2.46: 1$ \\
II & $4.23 \pm 0.68$ & $2.63 \pm 0.23$ & $1.61: 1$ & $3.28 \pm 1.08$ & $2.30 \pm 0.43$ & $1.43: 1$ \\
III & $1.93 \pm 0.71$ & $0.95 \pm 0.33$ & $2.03: 1$ & $3.31 \pm 0.78$ & $2.42 \pm 0.73$ & $1.37: 1$ \\
\hline
\end{tabular}

\section{CONCLUSIONS}

The fish oil used in the present experiment increased significantly $(\mathrm{P}<0.05)$ the CLA and omega -3 content in milk of buffaloes and improved the omega $-6 /-3$ relationship. In our region, where the animals are fed with nutritionally deficient natural pastures, supplementation with fish oil is an excellent strategy to increase the values of fatty acids. The possibility of increasing the concentration of these fatty acids through strategic supplementation, which is cost-effective, easily implemented and managed and does not alter the organoleptic properties of milk, is the challenge of research in the area of nutrition and technology of food.

\section{ACKNOLEDGEMENTS}

To Dr. Amrish Tyagi of the National Dairy Research Institute, Karnal, India, for his invaluable help. And to the National Agency for Promotion of Science and Technology
(ANPCyT) Argentina, for the funds contributed to PICTO-UNNE - 119.

\section{REFERENCES}

BELURY, M.A. Dietary conjugated linoleic acid in health: Physiological effects and mechanisms of action. Annu. Rev. Nutr., v.22, p.505-531, 2002.

BERGAMO, P.; FEDELE, E.; IANNIBELLI, L. et al. Fat-soluble vitamin contents and fatty acid composition in organic and conventional Italian dairy products. Food Chem., v.82, p.625-631, 2003.

CALDEIRA, L.A.; FERRAO, S.P.B.; FERNANDES, S.A.A. et al. Lipid profile of Murrah buffalo milk. Red. Vet., v.21, supl. 1, p.567-568, 2010.

CALDER, P.; DAVIS, J.; YAQOOB, P. et al. Dietary fish oil suppresses human colon tumour growth in athymic mice. Clin. Sci., v.94, p.303-311, 1998.

CANNIZZO, F.; BROITMAN, S. Postpromotional effects of dietary marine or safflower oils on large bowel on pulmonary implants of CT-26 in mice. Cancer Res., v.49, p.4289-4294, 1989. 
CHILLIARD, Y.; FERLAY, A.; MANSBRIDGE, R.M. et al. Ruminant milk fat plasticity nutritional control of saturated, polyunsaturated, trans and conjugated fatty acids. Ann. Zootech., v.49, p.181-205, 2000.

FEDELE, E.; IANNIBELLI, L., MARZILLO, G. Conjugated linoleic acid content in milk and mozarella cheese from buffalo feed with organic and traditional diet. In: WORLD BUFFALO CONGRESS. 6., Maracaibo. Proceedings IV World Buffalo Congress, Maracaibo. Venezuela. 2001. p.404-409.

GAGLIOSTRO, G.A. Manejo nutricional para la producción de leches de vaca y de cabra con alto impacto sobre la salud humana. Area de Investigación en Producción Animal. Ed. INTA- Balcarce y Facultad de Ciencias Agrarias UNMDP (Mar del Plata, Argentina). 2004. 84 p.

HA, Y.L.; STORKSON, J.; PARIZA, M.W. Inhibition of benzo(a)pyrene-induced mouse forestomach neoplasia by conjugated dienoic derivatives of linoleic acid. Cancer Res., v.50, p.1097-1101, 1990.

IP, C.; SING, M.; THOMPSON, H.J.; SCIMECA, J.A. Conjugated linoleic acid suppresses mammary carcinogenesis and proliferative activity of the mammary gland in the rat. Cancer Res. v.54, p.12121215, 1994.

INFOSTAT, 2009. InfoStata versión 2009. Grupo Infostat, Fac. Cs. Agrarias, Universidad Nacional de Cordoba, Argentina

ISO 15304. Animal and vegetable fats and oilsDetermination of the content of trans fatty acid isomers of vegetable fats and oils - Gas chromatographic method. 2002.

On

line: www.iso.org/iso/iso_catalogue/catalogue_tc/catalogu e_detail.htm.

LEE, K.N.; KRITCHEVSKY, D.; PARIZA, M.W. Conjugated linoleic acid and atherosclerosis in rabbits. Atherosclerosis. v.108, p.19-25, 1994.

MAIA, M.R.G.; CHAUDHARY, L.C.; BESTWIICK, C.S. et al. Toxicicty of unsaturated fatty acids to the biohydrogenating ruminal bacterium, Butyrivibrio fibrisolvens. BMC Microbiology, v.10, p.52, 2010.

MEDEIROS, S.R. Ácido linoléico conjugado: teores nos alimentos e seu uso no aumento da produção de leite com mayor teor de proteína e perfil de acidos graxos modificados. USP. 2002. 98f. Tese (Doutorado em Agronomia). Escola Sup.de Agricultura Luia de Queiroz. USP.
MENOTTI, A.; KROMHOUT, D.; BLACKBURN, H. et al. Food intake patterns and 25- year mortality from coronary heart disease: cross-cultural correlation in the seven countries study. The seven countries study research group. Eur. J. Epidemiol., v.15, p.507-515, 1999.

NATIONAL Research Council (NRC). Carcinogenesis and anticarcinogenesis in the human diet. National Academy Press. 1996. 242p.

NICOLOSI, R.J.; COURTEMANCHE, K.V.; LAITINEN, L. et al. Effect of feeding diets enriched in conjugated linoleic acid on lipoproteins and aortic atherogenesis in hamsters. Circulation, v.88, p.I-457, 1993

OLIVEIRA, R.L; LADEIRA, M.M.; BARBOSA, M.A.A.F. et al. Composição química e perfil de ácidos graxos do leite e muçarela de búfalas alimentadas com diferentes fontes de lipídeos. Arq. Bras. Med. Vet. Zootec., v.61, p.736-744, 2009.

PATIÑO, E.M.; JUDIS, M.A.; GUANZIROLI STEFANI, C. et al. Determinación de ácidos grasos en leche bubalina (Bubalus bubalis) producida en Corrientes, Argentina. Rev. vet., v.19, p.28-32, 2008

PATIÑO, E.M.; JUDIS, M.A.; GUANZIROLI STEFANI, C. et al. Conjugated linoleic acid and omega 6 and 3 in buffalo milk in Corrientes, Argentina. Red. Vet., v.21, supl. 1, p.244-248, 2010.

RAO, C.V.; HIROSE, Y.; INDRANIE, C. et al. Modulation of experimental colon tumorigenesis by types and amounts of dietary fatty acids. Cancer Res., v.61, p.927-1933, 2001.

REDDY, B.; SUGIE, S. Effect of different levels of $\omega$ 3 and $\omega-6$ fatty acids on azoxymethane-induced colon carcinogenesis in F344 rats. Cancer Res., v.48, p.6642-6647, 1998 .

SIMOPOULOS A.P. The importance of the ratio of omega-6/omega-3 essential fatty acids. Biomed Pharmacother, v.56, p.365-379, 2002.

SECCHIARI, P.; CAMPANILE, G.; MELE, M. et al. Fatty acid composition and CLA content of milk fat from Italian buffalo. 339-343. In: Indicators of milk and beff quality. EAAP Scientific Series $\mathrm{N}^{\circ} 112$. Edit by Hocquette and Gili. 2005. p.339-343.

TALPUR, F.N.; MEMON, N.N.; BHANGER, M.I. Comparison of fatty acid and colesterol content of Pakistani water buffalo breeds. Pak. J. Anal. Environ. Chem., v.8, p.15-20, 2007.

TALPUR, F.N.; BHANGER, M.I.; KHOOHARO, A.A. et al. Seasonal variation in fatty acid composition of milk ruminants reared under the traditional feeings system of Sindh, Pakistan. Livest. Sci., v.118, p.166172,2008 
Influence of fish oil...

TISDALE, M.; DHESI, J. Inhibition of weight loss by omega-3 fatty acids in am experimental cachexia model. Cancer Res., v.50, p.5022-5026, 1990.

TYAGI, A.K.; KEWALRAMANI, N.; DHIMAN, T.R. et al. Enhancement of the conjugated linoleic acid content of buffalo milk and milk products through green fodder feeding. Anim. Feed Sci. Technol., v.133, p.351-358, 2007.

VAN NIEUWENHOVE, C.; GONZALEZ, S.; PEREZ-CHAIA, A. et al. Conjugated linoleic acid in buffalo (Bubalus bubalis) milk from Argentina. Milchwissenschaft, v.59, p.9-10, 2004.
VAN NIEUWENHOVE, C.; GAUFFIN CANO, P; PEREZ-CHAIA, A. et al. Chemical composition and fatty acid content of buffalo cheese from northwest Argentina: effect on lipid composition of mice tissues. J. Food Lip., v, 14, p.223-243, 2007.

WILLIAMS, C.M. Dietary fatty acid and human health. Ann. Zootech., v.49, p.165-180, 2000 